\title{
Perception of Justice, Post Service Recovery Satisfaction, Intention to Revisit and Wom Recommendations of Foreign Tourists Visiting Bali
}

\section{Nyoman Sudiarta, Ni Wayan Sri Suprapti, and I Putu Gde Sukaatmadja}

\author{
School of Postgraduate Study \\ Doctorate Degree in Tourism Udayana University
}

Coressponding author: sudiarta.nyoman@yahoo.co.id

\begin{abstract}
ARTICLE INFO
Received

28 November 2013

Accepted

28 February 2014

Available online

10 March 2014
\end{abstract}

\begin{abstract}
This study aims to determine the effect of perceptions of distributive, procedural and interactional justice on post-service recovery satisfaction and post-service recovery satisfaction effect on the intention to revisit and WOM recommendations of foreign tourists to Bali. The respondents of this study were foreign tourists who visited Bali and ever experienced complaint. The number of eligible samples was 100 respondents. The questionnaire was given to tourists visiting tourist attractions of Tanah Lot, Kintamani and Besakih. Data were analyzed using multivariate statistical analysis, namely structural equation modeling (SEM). The results of this study indicated that the perception of distributive justice, procedural and interactional had a positive and significant effect on the post-service recovery satisfaction of foreign tourists who visited Bali. The study also found a positive and significant effect of post-service recovery satisfaction on the intention to revisit and the intention of recommending positive WOM of foreign tourists who visited Bali.
\end{abstract}

Keywords: distributive justice, procedural, interactional, service recovery satisfaction, intention to revisit, WOM recommendations, foreign tourists, Bali.

\section{Introduction}

\section{Background}

Various attempts were made by service providers to maintain and increase repeat visits of tourists to a tourist destination, such as improving the quality of service so that customers become satisfied. If consumers get a satisfactory experience, then this may lead to re-purchase behavior and recommend the experience to others. Engel et al (1995: 210 in Badawi, 2012) state that consumer satisfaction is an evaluation of various alternative options provided by service providers, at least meeting or exceeding customer expectations.

http://ojs.unud.ac.id/index.php/eot
The foregoing description can be interpreted that a customer will conduct an evaluation of his/her experience, whether his/her experience is in line with expectations or not. If the expectations of the customer are in accordance with the fact then he/she will feel satisfied. Conversely, if the expectations are not in accordance with reality, then the customer will feel discontent, which Oliver (1980) refers to it as disconfirmation. Expectation-disconfirmation model developed by Oliver (1980) is a concept that is used as a reference in the literature of marketing and manufacturing services to evaluate consumer behavior. Makens (2002) state that customer expectations are based on previous purchasing experience, even the opinion of friends and the promise of service providers. Further, it is 
stated that it is very important for service providers to maintain and improve services that meet or even exceed customer expectations. Furthermore it is stated that satisfied customers will make repeat purchases, no matter with prices and become loyal customers (Makens, 2002).

Dissatisfaction in some of the literatures is seen as a failure of the service (Wirtz and Mattila, 2004; Lovelock, 2007; Badawi, 2012). Among the behaviors complained of by Lovelock and Wirtz (2011) are due to the failure of the service, such as product returning, moving quietly, not wanting to buy another and providing negative information to others. The cause of the failure of the service according to Denham (1998 in Badawi, 2012), includes (1) failure caused by the company itself (40 percent), (2) the behavior of employees, such as being rude and unfriendly (20 percent), and (3) caused by the customer himself/herself (40 percent). By understanding the concepts contained in the marketing that the customer is everything, then attempt to do is revamping the company's internal problems and provide training on how to handle customers well.

Several studies have examined the service failure and recovery services such as Bell and Zemke (1987 in Badawi, 2012). Further there are five strategies that can be used to handle complaints, such as: (1) to apologize, (2) empathy, (3) award, (4) and (5) information on service failure and continued with presenting a prize. In line with the above opinion, Gautam (2011) in his study to identify strategies that can be used to restore the service as polite behavior (courtesy), honesty, providing explanations (offering explanations), empathy, endeavor, and an apology. Furthermore, Tax and Brown (1998 in Lovelock and Wirtz, 2011), state that nearly 85 percent of variations in service recovery satisfaction are determined by three dimensions of justice, namely procedural justice, interactional justice and distributive justice or the outcome.

Something that can be done by service providers to deal with complaints is to provide services quickly, to control the delay and flexibility (del Río-Lanza, Vázquez-Casielles and Díaz-Martín, 2009; Nikbin et al., 2011). Service recovery can be done with service recovery strategy based on interpersonal interaction in the delivery of services to consumers (Nikbin et al., 2010; Gautam, 2011). Further, the speed of treatment is also one strategy for dealing with complaints. The study on service recovery was also carried out by Nikbin et al. (2010), which examines complaints made by Iran Air flight. The study found a positive effect of distributive and interactional justice perceptions on service recovery satisfaction, influence perceptions of distributive justice is higher than the perceptions of interactional justice. Correspondingly, research conducted by Gautam (2011) also found the perception of distributive and interactional justice had an effect on recovery satisfaction of customer service in the aviation industry in India.

Research on satisfaction and service recovery has been done a lot, but there is still little research conducted on service recovery satisfaction in tourism destinations as well as the consequences of the continued behavior as a desire to repurchase and to have WOM information. Meanwhile, Nikbin et al. (2010); Gautam (2011) only examine the influence of perceptions of fairness with service recovery satisfaction. The study on service failure was confirmed by the results of the research by Mostert et al. (2009) which suggested a link between service failure and service recovery efforts. This has an impact on satisfaction and dissatisfaction with air travelers. Dissatisfaction occurs because of a nonoptimal service recovery effort that led to consumers reducing the frequency to fly back. This study used a social exchange theory (Homans, 1958), as the main theory and the theory of justice as an application theory. Social exchange theory is used to evaluate the service provider's response to customer complaints. Justice is the basis used to resolve conflicts between the customer and the service provider (Rawls, 2011; Pai, Yeh and Lin, 2012). Some researchers using the theory of justice were (Teo and Lim, 2001; Gautam, 2011; Pai, Yeh and Lin, 2012). Gautam (2011) used the theory of justice Rawls (2011) and equity theories to evaluate the service failure. Exchange implies that consumers expect compensation of costs incurred to acquire goods and services (Ghalandari, 2013). Furthermore, it is stated that there are three variables used to assess justice in the service 
industry, namely: (1) the perception of distributive justice, (2) procedural justice, and (3) interactional justice (McCollough, Berry and Yadav, 2000; Kuenzel and Katsaris, 2009; Lovelock and Wirtz, 2011; Pai, Yeh and Lin, 2012).

Distributive justice implies that when there is a failure of service and consumer grievances, then the consumer is entitled to compensation, such as discounts and rewards by service providers. Compensation for consumers is a right which must be obtained and an obligation of service providers to give it. Associated with this research, tourism destination managers or stakeholders in the tourism business are obliged to give a sense of fairness in the handling of complaints. While procedural fairness is the flexibility and efficiency of the handling of complaints, such as the ease and speed of the so-called procedural fairness. Consumers want to get the ease when they have complaints and get treatment quickly. If the complaints are dealt with quickly, so consumers feel justice, on the contrary, if the complaint is not dealt with quickly, it is perceived as not getting justice.

Furthermore, interactional justice is in the form of a complaint handling done in a friendly and thoughtful manner and there is an apology from the service provider, in the handling of complaints due to the failure of the service. Consumers will feel to get justice when there is an apology from service providers when dealing with complaints compared to not making an apology. The consequences of the grievance are the proposition in social exchange theory, namely the emergence of intention to make repeat purchases and reduce the negative WOM (Pai, Yeh and Lin, 2012). Pai, Yeh and Lin (2012) states that satisfaction after service recovery is an essential element in maintaining and expecting consumers' repeat visit. Furthermore, they declare that distributive justice and interactional justice had a positive and significant effect on the post-service recovery satisfaction of customer that uses aviation services in Taiwan. This indicates that the higher the distributive and interactional justice in the handling of complaints, the higher the customer satisfaction and causes a desire to repurcase and reduce the negative WOM recommendations.

http://ojs.unud.ac.id/index.php/eot
Associated with the study of post-service recovery, it was also conducted Nikbin et al. (2010), who examined the Iran Air flight industry. This study found a positive and significant influence perceptions of distributive and interactional justice on satisfaction of post-service recovery, and influence perceptions of distributive justice, higher than the perceptions of interactional justice. This is confirmed by research conducted Gautam (2011) who found that perceptions of distributive justice and interactional had an effect on post-service recovery satisfaction of customer in the aviation industry in India. To that end, this research seeks to explain the role of distributive justice, procedural justice and interactional justice in service recovery satisfaction and the role of service recovery satisfaction of the intention to revisit and WOM recommendations.

\section{Methodology}

This study was a survey of the unit of analysis in the form of individual or foreign tourists from countries with 10 big levels of visit to Bali. Sampling used non-probability, i.e. using purposive sampling (Jennings, 2001). Samples taken were as many as 150 , but the number of eligible samples was 100 respondents. The 100 samples met the requirements of the SEM analysis (Hair et al., 1995). Scale measurements used 5 point Likert scale. Data were analyzed using analysis techniques of Structural Equation Modeling (SEM). This study used a quantitative approach including: (1) descriptive statistical analysis needed to determine the frequency distribution of the answers from the questionnaire, and (2) inferential statistical analysis used to test the research hypothesis was Structural Equation Modeling (Hair et al., 1995; Latan, 2012; Dachlan, 2014; Santoso, 2014).

The variables used in this study were composed of the independent variables and the dependent variables. The independent variables consisted of: (1) the perception of distributive justice, (2) procedural justice, and (3) interactional justice, while the dependent variable consisted of: (1) the intention to revisit and (2) WOM recommendations. The details variables can be described as follows. 


\section{Distributive Justice}

Distributive justice is defined as the outcome or result perceived or received by tourists visiting the attractions in Bali The indicators used in this study was adapted from research of Kau and Wan-Yiun Loh (2006); Nikbin et al. (2010, 2011); Abdullah, Mohamad and Mokhlis (2011); Gautam (2011); Pai, Yeh and Lin (2012) which consists of:

a) Need (X1.1)

The definition of needs is the handling of complaints that are considered in accordance with the wishes and needs of tourists;

b) Justice (X1.2)

The definition of justice is an effort of tourists' complaints deemed to have given a sense of justice. The existence of fair treatment of the officers;

c) Compensation (X1.3)

The definition of compensation is the handling of complaints made by way of compensation; and

d) Value (X1.4)

The definition of value is an attempt of handling travelers' complaints considered to be valuable or beneficial.

\section{Procedural Justice}

Procedural justice is the service recovery process, which concentrates on flexibility and efficiency when tourists were visiting Bali. The indicators used in this study were adapted from Kau and Wan-Yiun Loh (2006); Gautam (2011); Pai, Yeh and Lin (2012), which consists of:

a) Opportunity (X2.1), an opportunity is defined as an opportunity given to covey a complaint in the event of failure of the service at a tourist attraction in Bali;

b) The speed (X2.2), the speed is defined as speed of service provided when dealing with complaints;

c) Responsibility (X2.3) responsibility is the responsibility of the service provider in recovery services to tourists visiting tourists' attraction in Bali; and

d) Difficulty (X2.4), the meaning of the difficulty is the difficulty experienced by tourists in expressing their complaints to the interested parties, such as the staff at a tourist attraction, tourist guides and travel agency.

http://ojs.unud.ac.id/index.php/eot

\section{Interactional Justice}

Interactional justice is a personal interaction when the service occurred between consumers and producers. Kim, Kim and Kim (2009) and Ghalandari, Babaeinia and Jogh (2012) state that the indicators used to assess interactional justice are: (1) courtesy, (2) respect, (3) interest, (4) careful listening, (5) effort, ( 6) trust, (7) explanation, (8) empathy, (9) apology, and (10) communication (in Wirtz and Mattila, 2004). However, the indicators used in this study refer to the research by Kau and Wan-Yiun Loh (2006); Nikbin et al. (2010, 2011) which consists of:

a) Communication (X3.1), the meaning of communication is the communication that occurs in the recovery service when visiting the tourist attraction in Bali;

b) Hospitality (X3.2), the definition of hospitality is hospitality service providers in dealing with complaints to the tourists who visit the tourist attraction in Bali;

c) Intention (X3.3), the meaning of intention is sincere intention of provider / officer in the service recovery when the tourists visit the tourist attraction in Bali; and

d) Apology (X3.4), the definition of apology is the apology made by recovery service providers when tourists visit the tourist attraction in Bali.

\section{Satisfaction of Post-Services Recovery}

This service satisfaction research is associated with restoration of services (service recovery) and failure (service failure), so that the term recovery satisfaction is introduced. The indicators or post-service recovery satisfaction attributes were adapted from research of Maxham and Netemeyer (2002); Wirtz and Mattila (2004); Neale and Murphy (2007); Badawi (2012) which include:

a) Explanation / communication (Y1.1)

The definition of explanation/communication is the satisfaction of the explanations given by the service provider in the recovery service to tourists visiting Bali;

b) Attitude / Behavior (Y1.2)

The definition of attitude /behavior is satisfaction with the attitude or behavior of service providers in service recovery efforts undertaken to tourists visiting Bali; 
c) Compensation (Y1.3)

Compensation is the satisfaction with the compensation awarded in the restoration of services to tourists visiting Bali;

d) Speed (Y1.4).

The definition of speed is satisfaction with the speed of service provided in the complaint handling for tourists when visiting Bali; and

e) Overall (Y1.5)

The meaning of overall is the overall satisfaction with the services provided in the handling of complaints to the tourists visiting Bali.

\section{Intention of Revisit}

Intention of revisit describes the behavior of tourists who intend to visit again to Bali tourism destinations because of satisfaction with service recovery that has been given. The indicators in this study were adapted from Valle et al. (2006); Kuenzel and Katsaris (2009); Pai, Yeh and Lin (2012) which consists of:

a) Revisit (Y2.1), which meansthe intention of tourists coming back to Bali;

b) Moving (Y2.2), moving means the tourist intention to move when there is dissatisfaction in service recovery when visiting Bali; and

c) Visiting although there is an increase in prices (Y2.3)

The definition of a visit even if there is a price increase is tourist intention to revisit to Bali, despite the expensiveness price.

\section{Intention of WOM Recommendations}

Intention to provide recommendations or Word of Mouth is a post-service recovery satisfaction rating reaction after a visit to Bali. The indicators WOM in this study was adapted from Kuenzel and Katsaris (2009); Pai, Yeh and Lin (2012), which consists of:

a) Telling others (Y3.1)

What is meant by telling others is tourists' intention to inform positive aspects to others to visit Bali;

b) Giving Suggestions (Y3.2)

The definition of giving suggestions is tourists' intention to suggest people visiting Bali; and

c) Encouraging (Y3.3)

What is meant by encouraging is the intention of tourists to encourage others to visit Bali.

\section{Results and Discussion}

\section{Demographic Characteristics of Respondents}

The results of data processing showed the demographic characteristics of respondents by age indicator, i.e. the majority of respondents aged 20-40 years totaling 40 percent. Based on sex, 55 percent of the respondents were female while the remaining 45 percent were male. Based on respondents' education, they were largely of Bachelor levels. Furthermore, based on the origin of the majority of respondents, or 49 percent were from Asia, followed by those originating from Australia.

Meanwhile, in terms of the occupation of the respondents, 36 percent of them were civil servants while private employees totaled 31 percent. In terms of the goal of the respondents visiting Bali travel destinations, most travelers had educational and vocational goals totaling respectively 36 and 34 percent. In connection with the complaints filed, most of the complaints were submitted to the guides totaling 41 percent, the manager of a tourist attraction 10 percent and they did not file a complaint totaling 26 percent.

Foreign tourists respondent types of complaints were caused by street vendors totaling 22 percent, cleanliness at tourist attraction 24 percent, the friendliness of the local guide 17 percent and too many businesses or many stalls 22 percent. As for the period of the visit of the respondents, mostly those who had repeated visits, amounting to 65 percent, and the respondents who made the first visit 35 percent.

\section{Testing of Goodness of Fit Model}

The results of testing of the goodness of fit overalls models according to the results of SEM analysis, the hypothetical model in this study was supported by empirical data, as presented in Table 1 below. 
Table 1. Test Results of Goodness of Fit Overall Model

\begin{tabular}{|c|c|c|c|}
\hline Criteria & $\begin{array}{l}\text { Cut- } \\
\text { off } \\
\text { value }\end{array}$ & Result & Description \\
\hline Chi- & Small & 234.410 & Good \\
\hline Square & & & Model \\
\hline p-value & $\geq 0.05$ & 0.320 & \\
\hline CMN/DF & $\leq 2.00$ & 1.042 & $\begin{array}{l}\text { Good } \\
\text { Model }\end{array}$ \\
\hline GFI & $\geq 0.90$ & 0.839 & Marginal \\
\hline AGFI & $\geq 0.90$ & 0.803 & Marginal \\
\hline TLI & $\geq 0.95$ & 0.976 & $\begin{array}{l}\text { Good } \\
\text { Model }\end{array}$ \\
\hline CFI & $\geq 0.95$ & 0.979 & $\begin{array}{l}\text { Good } \\
\text { Model }\end{array}$ \\
\hline RMSEA & $\leq 0.08$ & 0.021 & $\begin{array}{l}\text { Good } \\
\text { Model }\end{array}$ \\
\hline
\end{tabular}

Goodness of Fit Overall test results based on Table 1 indicated that 5 of the 7 criteria, namely p-value, TLI, CFI, CMIN / DF and RMSEA indicated good model. The best criteria used as an indication of goodness of a model is the value of Chi Square / DF which was less than 2, and RMSEA which was under 0,08 . In this study, the value CMIN / DF and RMSEA had met the cut-off value. Indicate that the structural model to test the causal relationship of justice constructs, post-service recovery satisfaction, intention to revisit, and WOM recommendations could be regarded as a good structural model. Thus SEM models in this research were suitable and feasible to be used, so that interpretation could be made for further discussion (Hair et al., 1995; Widarjono, 2010).

\section{Analysis of Structural Equation Modeling (SEM)}

In this structural model, it was tested five (5) hypothesized relationship between the variables (direct effect). The testing results of the relationship among the variables are presented in Table 2 as follows.
Table 2. Influence between Variables in Structural Models

\begin{tabular}{|c|c|c|c|}
\hline $\begin{array}{l}\text { Relationship } \\
\text { between } \\
\text { Variables }\end{array}$ & $\begin{array}{l}\text { Coefficie } \\
\text { nt }\end{array}$ & $\begin{array}{l}\mathrm{p}- \\
\text { value }\end{array}$ & $\begin{array}{l}\text { Descripti } \\
\text { on }\end{array}$ \\
\hline $\begin{array}{l}\text { Perceptions of } \\
\text { distributive } \\
\text { justice (X1) } \\
\rightarrow \\
\text { Satisfaction of } \\
\text { post-service } \\
\text { recovery (Y1) }\end{array}$ & 0,386 & $\begin{array}{l}0,000 \\
*\end{array}$ & $\begin{array}{l}\text { Significa } \\
\mathrm{nt}\end{array}$ \\
\hline $\begin{array}{l}\text { Perceptions of } \\
\text { procedural } \\
\text { justice (X2) }\end{array}$ & 0,187 & $\begin{array}{l}0,028 \\
*\end{array}$ & $\begin{array}{l}\text { Significa } \\
\mathrm{nt}\end{array}$ \\
\hline $\begin{array}{l}\rightarrow \\
\text { Satisfaction of } \\
\text { post-service } \\
\text { recovery (Y1) }\end{array}$ & & & \\
\hline $\begin{array}{l}\text { Interactional } \\
\text { justice } \\
\text { perceptions } \\
\text { (X3) } \rightarrow \\
\text { Satisfaction of } \\
\text { post-service } \\
\text { recovery (Y1) }\end{array}$ & 0,365 & $\begin{array}{l}0,000 \\
*\end{array}$ & $\begin{array}{l}\text { Significa } \\
\mathrm{nt}\end{array}$ \\
\hline $\begin{array}{l}\text { Post-service } \\
\text { recovery } \\
\text { satisfaction } \\
\text { (Y1) } \rightarrow \\
\text { Intention to } \\
\text { revisit (Y2) }\end{array}$ & 0,665 & $\begin{array}{l}0,011 \\
*\end{array}$ & $\begin{array}{l}\text { Significa } \\
\mathrm{nt}\end{array}$ \\
\hline $\begin{array}{l}\text { Post-service } \\
\text { recovery } \\
\text { satisfaction } \\
\text { (Y1) } \rightarrow \\
\text { WOM } \\
\text { Recommendat } \\
\text { ion (Y3) }\end{array}$ & 0,477 & $\begin{array}{l}0,000 \\
*\end{array}$ & $\begin{array}{l}\text { Significa } \\
\mathrm{nt}\end{array}$ \\
\hline
\end{tabular}




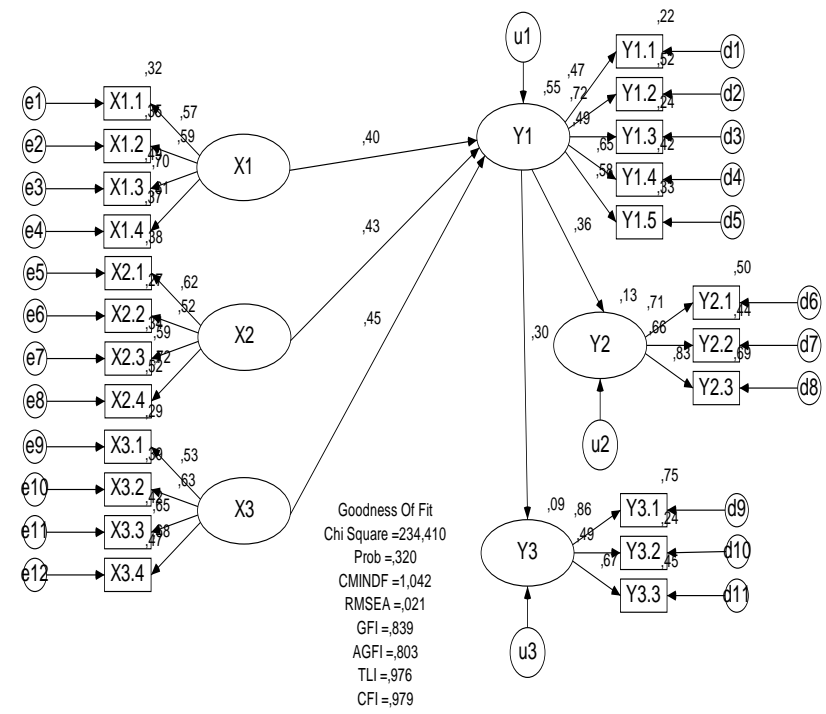

Figure 1. SEM Model of Justice Perceptions, Satisfaction of Post-Service Recovery, Intention to Revisit and WOM Recommendations.

Based on Table 2 and Figure 1 is presented the results of testing the structural model as follows:

1) Perceptions of distributive justice have a positive and significant effect on the postservice recovery satisfaction with the significance at $\mathrm{p}=0,000(<0,05)$ and a coefficient of 0.386 . This means that there is a significant effect between the perceptions of distributive justice on postservice recovery satisfaction. The coefficient being positive indicates that the relationship is directly proportional. This means that the higher perceptions of distributive justice, the post-service recovery satisfaction will also be higher. Conversely, the lower the perceived distributive justice is the lower the level of satisfaction after service recovery of tourists visiting Bali. Thus it can be stated that the hypothesis 1a is acceptable;

2) The perception of procedural justice has a positive and significant effect on the postservice recovery satisfaction with a significance of $\mathrm{p}=0,028(<0,05)$ and a coefficient of 0,187 . This means that there is a significant effect between the perceptions of procedural justice on satisfaction post-service recovery. The coefficient being positive indicates that the relationship is directly proportional. This means that the higher the perception of procedural fairness, the post- service recovery satisfaction will also be higher. Conversely the lower procedural justiceis then the lower the level of satisfaction after service recovery tourists visiting Bali. Therefore, hypothesis of $1 \mathrm{~b}$ is acceptable;

3) Perceptions of interactional justice has a positive and significant effect on post service recovery satisfaction with significance at $p=0,000(<0,05)$ with a coefficient of 0,365 . This means that there is a significant effect between the perceptions of interactional justice on satisfaction of post-service recovery. The coefficient being positive indicates that the relationship is directly proportional. This means that the higher perceptions of interactional justice, the post-service recovery satisfaction will also be higher and vice versa. Thus, it can be stated that the hypothesis $1 \mathrm{c}$ is acceptable;

4) Post-service recovery satisfaction has a positive and significant effect on intention to revisit with $\mathrm{p}=0,011(<0,05)$ with a coefficient of 0,665 . This means that there is a significant effect between the postservice recovery satisfaction on the intention to revisit.The coefficient being positive indicates that the relationship is directly proportional. This means that the higher the post-recovery satisfaction of services the intention to revisit also will be higher. Conversely the lower the perceived satisfaction is then the lower the desire to come back. Thus, it can be stated that the hypothesis $2 \mathrm{a}$ is acceptable; and

5) Post-service recovery satisfaction has a positive and significant influence on the recommendation of WOM with $\mathrm{p}=0,000$ $(<0,05)$ with a coefficient of 0,477 . This means that there is a significant effect between the post-service recovery satisfactions on WOM recommendation. The coefficient being positive indicates that the relationship is directly proportional. This means that the higher the satisfaction of the service recovery after WOM recommendations will also be higher. In contrast the lower the postservice recovery satisfaction the lower the desire to provide a positive WOM recommendation. Thus, it can be stated that the hypothesis $2 b$ is acceptable. 
Based on Table 1, 2 and Figure 1 and the results of the descriptive analysis based on the demographics of the respondents some of the findings of the complaint behavior of foreign tourists visiting Bali is still a reluctance of travelers to make a complaint directly (26 percent), this reinforces the results of research by Lovelock and Wirtz (2011) which states as much as 19 to 30 percent of customers are reluctant to make a complaint. This led to a situation that the complaint cannot be handled properly. The next finding of this study was in the form of a research model based on recovery services applied to tourism destinations. This finding is supported by the results of goodness of fit index qualified for fitness of model according to (Hair et al., 1995).

The main findings of the study are: (1) the effect of perceptions of justice on satisfaction of post-services recovery which confirmed study of Kim, Kim and Kim (2009); Nikbin et al. (2010); Gautam (2011), (2) the effect of procedural justice perceptions on the satisfaction of the service recovery which supported research Kim, Kim and Kim (2009); Nikbin et al. (2010); Badawi (2012); Pai, Yeh and Lin (2012), (3) the effect of interactional justice on satisfaction after service recovery is consistent with the results of the study by Kim, Kim and Kim (2009); Nikbin et al. (2010); Gautam (2011); Badaw, (2012); Pai, Yeh and Lin (2012), (4) Effect of service recovery satisfaction of the intention to revisit in line with the results of Kim, Kim and Kim (2009); Pai, Yeh and Lin (2012), (5) the effect of perceptions of justice to the WOM recommendations showed results consistent with the study of Kim, Kim and Kim (2009); Pai, Yeh and Lin (2012).

\section{Conclusion and Recommendation}

\section{Conclusion}

The perception of distributive justice has a positive and significant effect on the postservice recovery satisfaction. This means that the higher the perceptions of distributive justice, the post-recovery satisfaction service will also be higher and vice versa; the perception of procedural justice has a positive and significant effect on the post-service recovery satisfaction. This indicates that the higher the perception of procedural fairness, the post-service recovery satisfaction will also be higher and vice versa;

The perception of interactional justice has a positive and significant effect on the postservic recovery satisfaction. It shows the higher perceptions of interactional justice; the post- service recovery satisfaction will also be higher and vice versa. Post-service recovery satisfaction has a positive and significant effect on intention to revisit. This means that the higher the satisfaction of post- service recovery then intention to revisit also will be higher as well and vice versa. Post-service recovery satisfaction has a positive and significant influence on the recommendation of WOM. To that end, this research found that the higher the indicator of satisfaction postservice recovery, the WOM Recommendations will also be higher and vice versa.

\section{Recommendation}

To increase tourist satisfaction during post-service recovery by government and tourism players, there is a need to apply marketing strategies based on tourism destination perceptions of distributive justice by providing compensation in the event of service failure. Applying procedural justice based strategy is to increase the speed of service in the event of service failure. Applying a recovery strategy based on services interactional justice is done by making an apology if there are failures of service.

To increase repeat visits and WOM recommendations to foreign tourists visiting Bali can be done by increasing the post-service recovery satisfaction. The strategies that can be used are as follows: (1) providing a good explanation to tourists when dealing with complaints, (2) handling complaints with a good attitude, such as greetings and expressing thanks, (3) providing adequate compensation based on the type of service failure, (4) dealing with complaints quickly so as to increase repeat visits and positive WOM. (5) Using mixed strategy of service recovery satisfaction to increase revisit and positive WOM recommendations. 


\section{References}

Abdullah, A. R., Mohamad, M. and Mokhlis, S. (2011) 'Examining the Structural Relationships of Service Recovery, Destination Image and Behavioural Intentions of Foreign Tourists: A Proposal'.

Badawi (2012) 'Peran Emosi Memediasi Keadilan Distributif, Prosedural dann Interaksional Terhadap Kepuasan Pemulihan Layanan', Jurnal Manajemen dan Akuntansi, 1(1), pp. 13-26.

Dachlan, U. (2014) 'Panduan Structural Equation Modeling', Semarang: Lentera Ilmu.

Gautam, V. (2011) 'Investigating the moderating role of corporate image in the relationship between perceived justice and recovery satisfaction: evidence from Indian aviation industry', International Review of Management and Marketing. EconJournals, 1(4), p. 74.

Ghalandari, K. (2013) 'Perceived Justice's Influence on Post-Purchase Intention s and Post-Recovery Satisfaction in Online Purchasing: the Moderating Role o f Firm Reputation in Iran', Research Journal of Applied Sciences, Engineerin $g$ and Technology, 5, pp. 1022-1031.

Ghalandari, K., Babaeinia, L. and Jogh, M. G. G. (2012) 'Investigation of the effect of perceived justice on post-recovery overall satisfaction, post-recovery revisit intention and post-recovery word-of-mouth intention from airline industry in Iran: The role of corporate image', World Applied Sciences Journal, 18(7), pp. 957-970.

Hair, J. F., Anderson, R. E., Tatham, R. L. and Black, W. C. (1995) 'Multivariate Data Analysis with Readings, Prentice Hall Englewood Cliffs', NJ Google Scholar.

http://ojs.unud.ac.id/index.php/eot
Homans, G. C. (1958) 'Social behavior as exchange', American journal of sociology. University of Chicago Press, 63(6), pp. 597-606.

Jennings, G. (2001) Tourism research. John Wiley and sons Australia, Ltd.

Kau, A.-K. and Wan-Yiun Loh, E. (2006) 'The effects of service recovery on consumer satisfaction: a comparison between complainants and noncomplainants', Journal of Services Marketing. Emerald Group Publishing Limited, 20(2), pp. 101-111.

Kim, T. T., Kim, W. G. and Kim, H.-B. (2009) 'The effects of perceived justice on recovery satisfaction, trust, word-ofmouth, and revisit intention in upscale hotels', Tourism Management. Elsevier, 30(1), pp. 51-62.

Kuenzel, S. and Katsaris, N. (2009) 'A critical analysis of service recovery processes in the hotel industry', TMC Academic Journal. TMC Academy, Singapore, 4(1), pp. 1-11.

Latan, H. (2012) 'Structural equation modeling: Konsep dan aplikasi menggunakan program LISREL 8.80', Bandung: Alfabeta.

Lovelock, C. (2007) Services Marketing People, Technology, Strategy, 5/e. Pearson Education India.

Lovelock, C. H. and Wirtz, J. (2011) Service Marketing. People, Technology, Strategy 6e. United State of America: Pearson Prentice Hall.

Makens, J. (2002) 'Pemasaran Perhotelan Dan Kepariwisataan', Jakarta: Prenhallindo.

Maxham, J. G. and Netemeyer, R. G. (2002) 'Modeling customer perceptions of complaint handling over time: the effects of perceived justice on satisfaction and intent', Journal of retailing. Elsevier, 78(4), pp. 239252. 
McCollough, M. A., Berry, L. L. and Yadav, M. S. (2000) 'An empirical investigation of customer satisfaction after service failure and recovery', Journal of service research. Sage Publications Sage CA: Thousand Oaks, CA, 3(2), pp. 121-137.

Neale, L. and Murphy, J. (2007) 'Perceived justice and email service recovery', Australasian Marketing Journal. Monash University, 15(3), p. 5.

Nikbin, D., Armesh, H., Heydari, A. and Jalalkamali, M. (2011) 'The effects of perceived justice in service recovery on firm reputation and repurchase intention in airline industry', African journal of business Management. Academic Journals, 5(23), p. 9814.

Nikbin, D., Ismail, I., Marimuthu, M. and Jalalkamali, M. (2010) 'Perceived justice in service recovery and recovery satisfaction: the moderating role of corporate image', International Journal of Marketing Studies, 2(2), p. 47.

Oliver, R. L. (1980) 'A cognitive model of the antecedents and consequences of satisfaction decisions', Journal of marketing research. JSTOR, pp. 460469.

Pai, F.-Y., Yeh, T.-M. and Lin, L.-Y. (2012) 'The effects of perceived justice on service recovery satisfaction and postpurchase behaviors-with the moderating effect of consumer experiences', in The. 大葉大學 休閒事業管理學系.

Rawls, J. (2011) A Theory of Justice Teori Keadilan, Dasar-dasar Filsafat Politik untuk Mewujudkan Kesejahteraan Sosial dalam Negara. Edited by U. F. and H. Prasetyo. Yogyakarta: Pustaka Pelajar. del Río-Lanza, A. B., Vázquez-Casielles, R and Díaz-Martín, A. M. (2009) 'Satisfaction with service recovery: Perceived justice and emotional responses', Journal of Business Research. Elsevier, 62(8), pp. 775781.

Santoso, S. (2014) 'Statistik Multivariat Edisi Revisi Konsep dan Aplikasi dengan SPSS'. Jakarta: PT. Elex Media Komputindo.

Teo, T. S. H. and Lim, V. K. G. (2001) 'The effects of perceived justice on satisfaction and behavioral intentions: the case of computer purchase', International Journal of Retail \& Distribution Management. MCB UP Ltd, 29(2), pp. 109-125.

Valle, P. O. do, Silva, J. A., Mendes, J. and Guerreiro, M. (2006) 'Tourist satisfaction and destination loyalty intention: a structural and categorical analysis', International Journal of Business Science and Applied Management. Matopoulos, Aris, 1(1), pp. 25-44.

Widarjono, A. (2010) 'Analisis statistika multivariat terapan', UPP STIM YKPN, Yogyakarta.

Wirtz, J. and Mattila, A. S. (2004) 'Consumer responses to compensation, speed of recovery and apology after a service failure', International Journal of service industry management. Emerald Group Publishing Limited, 15(2), pp. 150-166. 